\title{
Pengaruh Persepsi tentang Program Pendidikan Profesi Guru (PPG) dan Profesi Guru terhadap Minat Mahasiswa untuk Menjadi Guru
}

\author{
Beti Anggraini $^{1 *}$, Akmal Hawi ${ }^{2}$, Ahmad Zainuri ${ }^{3}$ \\ 1,2,3 UIN Raden Fatah Palembang, Indonesia
}

\begin{abstract}
Abstrak: Minat merupakan suatu keinginan dari dalam diri seseorang yang timbul karena adanya ketertarikan terhadap sesuatu yang akan menimbulkan rasa keingintahuan yang tinggi dalam diri seseorang. Penelitian ini merupakan jenis penelitian yang bersifat asosiatif kausal dan pendekatan dalam penelitian ini menggunakan pendekatan kuantitatif, penelitian dilakukan pada bulan Maret sampai April 2020 di Fakultas Ilmu Tarbiyah dan Keguruan Universitas Islam Negeri Raden Fatah Palembang, sampel penelitian berjumlah 152 orang siswa Program Studi Pendidikan Guru Madrasah Ibtidaiyah dengan menggunakan Nomogram Herry King dengan taraf kesalahan 5\%. Hasil penelitian menunjukkan terdapat pengaruh positif persepsi mahasiswa tentang program pendidikan profesi guru (PPG) (sebesar 0,723 dengan nilai t sebesar 9,139 dan signifikansi 0,000) dan profesi guru (sebesar 0,201 dengan nilai t sebesar 3,994 dan signifikansi 0,000) terhadap minat menjadi guru pada mahasiswa Program Studi Pendidikan Guru Madrasah Ibtidaiyah Universitas Islam Negeri Raden Fatah Palembang.
\end{abstract}

Kata Kunci: minat, persepsi, pendidikan profesi guru, profesi guru

\begin{abstract}
Interest is a desire from within a person that arises because of an interest in something that will create a high sense of curiosity in a person. This research is a type of research that is causal associative and the approach in this research uses a quantitative approach, the study was conducted from March to April 2020 at the Faculty of Tarbiyah and Teaching Sciences, Raden Fatah State Islamic University, Palembang, the research sample was 152 students of the Ibtidaiyah Madrasah Teacher Education Study Program using the Herry King Nomogram with an error rate of 5\%. The results showed that there was a positive influence on students' perceptions of the teaching professional education program (PPG) (amounting to 0.723 with a t value of 9.139 and a significance of 0.000 ) and the teaching profession (of 0.201 with a t value of 3.994 and a significance of 0.000 ) on the interest in becoming a teacher in Ibtidaiyah Madrasah Teacher Education Study Program students, Raden Fatah State Islamic University, Palembang.
\end{abstract}

Keywords: interests, perceptions, teacher profession education, teacher profession

\section{Pendahuluan}

Profesi dimaknai sebagai segala bentuk kegiatan yang dilaksankan oleh seseorang guna mendapatkan nafkah berdasarkan kemampuan khusus yang ada padanya (Khairani, 2017). Profesi bermakna menyerahkan dan mengabdikan diri seutuhnya kepada suatu macam pekerjaan, mengemban tanggung jawab bagi diri pribadi maupun kepada masyarakat (Arifin, 2011). Profesi mempunyai ciri utama berupa: 1) adanya pengakuan dari masyarakat sebagai wujud pengabdian bagi kepentingan umum; 2) memiliki

\footnotetext{
* Corresponding Author: Beti Anggraini (betianggraini96@gmail.com). UIN Raden Fatah Palembang, Indonesia
}

ISSN 1412-1697 (Print); ISSN 2477-3816 (Online) 
kekhususan dalam hal keterampilan dengan kaidahkaidah dan lembaga khusus yang dapat dipertanggung jawabkan secara luas; 3) memiliki kaidah atau aspek keilmuan yang bersifat rasioanal; dan 4) terdapat sistem imbalan baik finansial maupun materiil, yang disepakati oleh masyarakat dimana besarannya sangat tergantung jenis dan spesifikasi pekerjaan yang dilakukan. Definisi profesional merujuk pada Undang-Undang Republik Indonesia Nomor 14 Tahun 2005 Pasal 1 ayat 4, menyatakan bahwa profesional ialah pekerjaan maupun kegiatan yang dikerjakan oleh seseorang dan berperan sebagai sarana penghasilan dengan keahlian tertentu dengan standar baku formal, dimana keahlian yang dimaksud diperoleh melalui proses pendidikan profesi. Profesionalisme merupakan isyarat berupa pernyataan bahwa suatu pekerjaan profesional hanya mampu ditunaikan oleh pribadi-pribadi tertentu yang secara terencana telah dipersiapkan untuk maksud tersebut, sehingga pekerjaan tersebut bukanlah pekerjaan yang dilakukan bagi mereka yang mengerjakannya disebabkan oleh karena tidak memiliki pekerjaan lainnya (Husein L, 2017).

Merujuk pada definisi dan ciri profesi tersebut menegaskan bahwa guru adalah profesi yang ideal dengan bidang keahlian spesifik dengan derajat keilmuan yang relative lebih tinggi dibandingkan dengan profesi lainnya untuk menjadi guru seseorang harus menempuh pendidikan tinggi dan mengikuti program pendidikan profesi guru secara formal. Profesi guru bukan saja menuntut keahlian yang didasarkan pada kemampuan melalui kaidah teori akademis semata namun juga menuntut kemampuan khusus terutama bidang psikologi, etika dan moralitas yang memadai. Disamping pendidikan formal dan konsep keilmuan dalam bidang akademis, guru yang ideal adalah pribadi yang dilengkapi dengan: minat, bakat, komitmen, keimanan, ketakwaan, budi pekerti, idealisme dan panggilan jiwa (Syah, 2013).

Terdapat lima parameter profesionalisme guru yakni: 1) mempunyai komitmen kuat kepada para peserta didik termasuk proses edukasinya; 2) memiliki kemampuan dalam pendalaman materi ajar dan cara mentransfer materi ajar tersebut; 3) memiliki tanggung jawab dalam mengawasi kemajuan intelektual para peserta didik menggunakan beragam metode evaluasi; 4) berfikir terarah dan tersistem manakala mengemban tugas; dan 5) berperan aktif sebagai bagian penting dalam komunitas belajar dalam lingkup profesi guru. Menurut Journal Education Leadership, dikukuhkannya guru menjadi suatu bidang profesi menimbulkan konsekuensi berupa adanya kewajiban bagi semua guru untuk berperan aktif guna melakukan restrukturisasi model pembelajaran ke arah yang makin maju dan modern dengan memanfaatkan segala bentuk sumber daya secara optimal (Supriadi, 1998).

Profesi guru dalam perspektif Islam bukan saja sebagai sarana pekerjaan untuk mencari nafkah, namun lebih kepada sarana ibadah dan pengabdian diri pada perintah Allah Swt. Profesi guru bukanlah profesi dengan tanggung jawab yang ringan, guru bertugas sebagi pribadi yang memberikan pembelajaran dan pendidikan bagi banyak orang dalam rangka mendesain masa depan yang baik, hasil pekerjaan guru dapat dirasakan pada masa yang akan datang atau jangka panjang. Diperlukan ketulusan dan sikap gigih yang muncul dari dalam pribadi seorang guru dalam upayanya mendidik generasi baru agar dicapai peradaban yang lebih baik di masa depan khusunya dalam lingkup kehidupan bernegara yang berwawasan kebangsaan. Di samping mengemban kewajiban mengajar, guru dituntut pula mengembangkan keahlian dan kompetensinya dalam hal 
pengetahuan dan teknologi pendukungnya (Hidayatullah, 2009).

Pada tahun 2005 menjadi momentum bersejarah bagi bidang profesi kependidikan dengan ditetapkannya Undang-Undang Nomor 14 Tahun 2005 tentang guru dan dosen, yang secara eksplisit menjelaskan bahwasanya pekerjaan guru adalah suatu bidang profesi. Petunjuk teknis bagi penyiapan guru selaku bidang profesi dirumuskan melalui Peraturan Pemerintah Nomor 74 Tahun 2008 tentang guru. Petunjuk yang dimaksud menetapkan bahwa guru wajib memiliki kualifikasi pendidikan formal pada jenjang strata 1, selanjutnya guru diwajibkan pula mempunyai sertifikat profesi pada bidang kependidikan yang didapat dari pendidikan khusus profesi guru. Acuan formal tentang lingkup profesi guru juga tertuang pada Undang-Undang Nomor 12 Tahun 2012 tentang Pendidikan Tinggi pasal 17 ayat (1) yang mengisyaratkan bahwasanya pendidikan bidang profesi guru adalah pendidikan tinggi lanjutan setelah studi jenjang strata yang ditempuh dalam rangka mempersiapkan para lulusan agar memenuhi kualifikasi keahlian pada bidang kependidikan yang akan ditekuninya. Untuk menekuni profesi guru seseorang yang telah memiliki jenjang kependidikan pada jenjang strata satu diwajibkan memiliki sertifikat pendidik yang didapatkannya dengan cara mengikuti program pendidikan guru. Program ini adalah program yang diselenggarakan dalam rangka memenuhi standar keahlian profesi keguruan yang mencakup aspek standar terkait pada pendidikan, penelitian dan pengabdian masyarakat, dengan kata lain melalui perangkat formal sistem perundangan yang mengatur tentang profesi bidang kependidikan ini secara formal memberikan peluang bagi siapa saja yang memiliki minat dan kemampuan untuk berprofesi sebagai guru, dan tidak terbatas hanya pada sarjana bidang kependidikan saja.
Program Pendidikan Profesi Guru (PPG) adalah kegiatan lanjutan untuk mendidik seseorang agar menjadi guru profesional setelah ia menyelesaikan pendidikan formal pada jenjang strata satu atau sarjana. Program PPG menjadi syarat tertentu yang harus dijalani melalui studi selama satu tahun hingga dua tahun. Adapun tujuan pokok dari program PPG ialah untuk melengkapi kompetensi para calon guru yang sesuai dengan standar kompetensi profesi guru, sehingga para guru nantinya mendapat legitimasi formal dari Negara dan masyarakat terkait profesionalitasnya setara dengan profesi lainnya (Yahya, 2013).

Motivasi tertinggi bagi seorang guru adalah manakala masyarakat luas menyematkan gelar istimewa yakni sebagai pahlawan tanpa tanda jasa. Penghargaan yang demikian tinggi merupakan cerminan harapan dan keinginan yang sangat tinggi kepada guru, peran guru teramat komlpleks bagi sebuah tatanan peradaban, alasannya adalah karena seluruh perangkat masyarakat dari birokrat hingga tenaga profesional merupkan produk nyata dari sebuah sistem pendidikan dimana guru merupakan actor utamanya. Kenyataan demikianlah yang senantiasa dijadikan motivasi bagi setiap mahasiswa bidang kependidikan dalam menempuh dan menyelesaikan studinya (Hamalik, 2010).

Membentuk seorang guru yang mampu memenuhi harapan masyarakat bukan lah hal mudah yang dapat dicapai dalam tempo singkat, dibutuhkan proses panjang, sistematis dan terukur untuk tujuan tersebut. Namun demikian sikap pesimistik semacam ini bukan dimaksudkan untuk menurunkan minat seseorang untuk menjadi guru, bahkan sebaliknya menjadi faktor pemotivasi yang sempurna bagi upaya menjaga semangat dan daya juang para mahasiswa pada bidang kependidikan. Membangun minat menjadi pekerjaan tersendiri yang harus mendapatkan perhatian khusus, hal ini 
untuk menghindari terjadinya disorientasi berupa fenomena yang berlangsung dimasyarakat yang menyuguhkan kenyataan bahwa justru banyak alumni pergurun tinggi bidang kependidikan yang seharusnya menjadi guru justru beralih profesi pada bidang lain, misalnya politikus dan para pengusaha (Djam'an, 2007).

Beragam faktor dominan yang berpengaruh terhadap minat para mahasiswa memilih profesi guru pada program studi pendidikan akuntansi adalah: latar belakang pendidikan, pandangan positif terhadap bidang pekerjaan guru, pengetahuan terkait profesi guru termasuk lingkup tugas dan tanggung jawabnya, pandangan terhadap taraf ekonomi guru, lingkungan sosial dan motivasi baik dari dalam diri yang bersangkutan maupun motivasi yang bersumber dari luar pribadi para mahasiswa tersebut (Baharuddin \& Makin, 2010).

Masalah mendasar yang dihadapi guru dalam melaksanakan profesionalitasnya antara lain adalah kompetensi, distribusi dan kesejahteraan. Berdasarkan banyak kajian kompetensi guru di Indonesia terdapat kesenjangan pengetahuan, keterampilan dan keahlian para guru dari tingkat dasar hingga menengah, kewajiban pemenuhan pendidikan formal pada jenjang kesarjanaan belum mampu menjawab persoalan terkait kompetensi guru tersebut, upaya lain ditempuh melalui kursuskursus dan pelatihan-pelatihan keahlian yang mampu menunjang kelancaran aktifitas guru dilapangan. Distribusi ataupun sebaran guru masih menjadi persoalan serius dimana guru lebih banyak terkonsentrasi dikota-kota dan populasi guru didaerah terpencil masih sangat minim, dengan postur sebaran yang tidak proporsional semacam ini akan berdampak pada turunnya minat orang untuk memilih profesi guru. Rumitnya distribusi guru pada wilayah Indonesia diperparah dengan kenyataan bahwa postur anggaran pendidikan yang dialokasikan bagi penambahan jumlah tenaga guru (yang berstatus pegawai negeri sipil) makin mengalami penurunan yang tentunya berdampak pada makin merosotnya minat orang untuk memilih guru sebagai profesinya (Slameto, 2015).

\section{Metode Penelitian}

Penelitian ini menggunakan pendekatan kuantitatif. Sampel yang diambil adalah 152 dari 278 mahasiswa pada program studi Pendidikan Guru Madrasah Ibtidaiyah angkatan 2017. Data diperoleh dari kuisioner dan dokumentasi. Teknik analisis data yang dipakai adalah teknik analisis deskriptif, uji prasyarat analisis (uji normalitas, uji linieritas, kolinearitas), uji hipotesis (uji simultan, uji parsial) serta menghitung sumbangan relatif dan sumbangan efektif.

\section{Hasil Penelitian dan Pembahasan}

\section{Deskripsi Hasil Penelitian}

Penelitian ini dilakukan di Program Studi Pendidikan Guru Madrasah Ibtidaiyah (PGMI) Universitas Islam Negeri Raden Fatah Palembang dengan sampel penelitian mahasiswa angkatan 2019, yang terdiri dari 7 kelas. Data penelitian ini adalah persepsi mahasiswa tentang program PPG (X1), persepsi mahasiswa tentang profesi guru (X2), dan minat menjadi guru (Y). Selanjutnya akan ditampilkan deskripsi hasil dari data penelitian pada masing-masing variabel yang didapat dari lapangan. Deskripsi ini menyajikan modus, median, mean, standar deviasi, nilai maksimum, nilai minimum dan deskripsi frekuensi untuk masing-masing variabel, berikut ini adalah uraian secara detil masing-masing variabel data tersebut.

1. Minat mahasiswa menjadi guru (variabel Y)

Variabel Y mempunyai 17 butir pernyataan valid dengan total responden penelitian berjumlah 152 mahasiswa. Pada data Y ini didapat hasil pada nilai maksimum 80 dengan nilai minimum 34; 
Modus (Mo) 63; Median (ME) 63,00; Mean (M) 63,03; dan Standar Deviasi (SD) 7,903.

Kuantitas kelas interval sebesar 8 kelas didapatkan melalui penggunaan rumus $1+3,3 \mathrm{log}$ $\mathrm{n}(1+3,3 \log 152=8,2)$. Selanjutnya rentang data dalam variabel sebesar $80-34=46$, setelah diketahuinya nilai rentang data maka diketahui panjang kelas interval untuk masing-masing kelompok yaitu 46/8 = 5,75 dengan dibulatkan menjadi 6. Pada tabel berikut ini ditunjukkan distribusi frekuensinya.

Tabel 1. Distribusi Frekuensi Variabel Minat menjadi Guru

\begin{tabular}{|c|c|c|c|}
\hline No. & Interval & Frekuensi & Persentase \\
\hline 1. & $34-39$ & 1 & 0,66 \\
\hline 2. & $40-45$ & 1 & 0,66 \\
\hline 3. & $46-51$ & 12 & 7,90 \\
\hline 4. & $52-57$ & 18 & 11,84 \\
\hline 5. & $58-63$ & 47 & 30,92 \\
\hline 6. & $64-69$ & 45 & 29,60 \\
\hline 7. & $70-75$ & 16 & 10,52 \\
\hline 8. & $76-81$ & 12 & 7,90 \\
\hline \multicolumn{2}{|c|}{ Total } & 152 & 100 \\
\hline
\end{tabular}

Distribusi frekuensi pada tabel di atas disajikan dengan diagram batang dalam gambar 1 berikut ini:

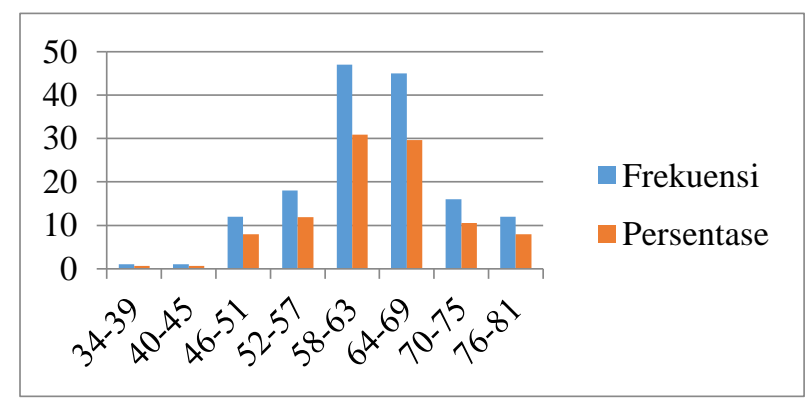

Gambar 1. Diagram Distribusi Frekuensi Minat menjadi Guru

Berikutnya variabel dikategorikan guna melihat seberapa besar kecondongan masingmasing variabel, sehingga terdapat 5 kategori dengan rincian sebagai berikut:
Tabel 2. Pengkategorian Variabel Minat menjadi Guru

\begin{tabular}{|c|c|c|c|}
\hline No. & Kategori & Frekuensi & Persentase \\
\hline 1. & Sangat tinggi $(\mathrm{X}>68,49)$ & 32 & 21,05 \\
\hline 2. & Tinggi $(60,83<\mathrm{X} \leq 68,49)$ & 72 & 47,37 \\
\hline 3. & $\begin{array}{c}\text { Sedang }(53,17)<\mathrm{X} \leq \\
60,83)\end{array}$ & 31 & 20,40 \\
\hline 4. & $\begin{array}{c}\text { Rendah }(45,51)<\mathrm{X} \leq \\
53,17)\end{array}$ & 15 & 9,87 \\
\hline 5. & Sangat rendah $(\mathrm{X} \leq 45,51)$ & 2 & 1,31 \\
\hline \multicolumn{2}{|c|}{ Total } & 152 & 100 \\
\hline
\end{tabular}

Dari tabel 2 dapat dilihat bahwasanya minat menjadi guru (variabel Y) memiliki kecondongan pada level tinggi berjumlah 72 reponden dengan persentase sebesar $47,37 \%$, diikuti level sangat tinggi berjumlah 32 orang dengan persentase sebesar $21,05 \%$, selanjutnya level sedang sebanyak 31 orang dengan persentase sebesar 20,40\%, kemudian rendah sebanyak 15 orang atau 9,87\% dan sangat rendah sebanyak 2 orang atau 1,31\%

Varibel Y (minat menjadi guru) mencapai nilai komulatif pada kisaran 63,03 pada posisi kelas interval tinggi, maka patut dinyatakan bahwasanya variabel Y terbilang pada kategori tinggi. Mengacu pada tabel 12, varibel $\mathrm{Y}$ diilustrasikan dengan gambar 2 berikut ini:

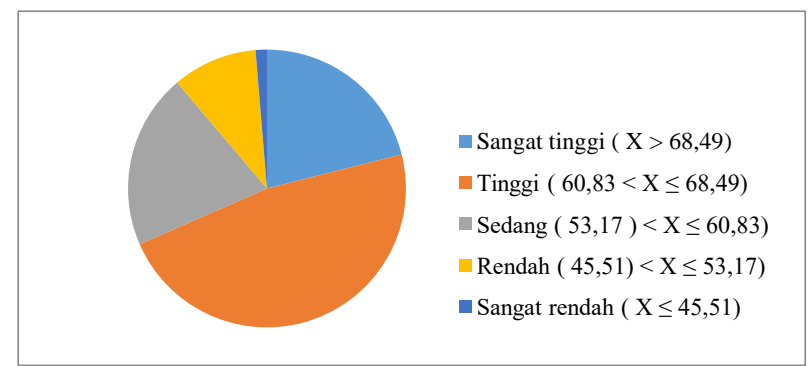

Gambar 2. Diagram Lingkaran Pengkategorian Variabel Minat menjadi Guru

2. Persepsi mahasiswa tentang program PPG (Variabel $\mathrm{X}^{1}$ )

Variabel $\mathrm{X}^{1}$ mempunyai 13 butir pernyataan valid melalui responden sejumlah 152 mahasiswa. Hasil analisis variabel $\mathrm{X}^{1}$ ini berupa: nilai 
maksimum 60; nilai minimum 34; Modus (Mo) 46; Median (ME) 46,00; Mean (M) 46,49; dan Standar Deviasi (SD) 6,347. Jumlah kelas interval diperoleh sejumlah 8 kelas yang diperoleh dengan menggunakan rumus $1+3,3 \log$ n. $(1+3,3 \log 152)$ $=8,2$ Untuk rentang data dalam variabel ini yaitu sebesar $60-34=26$, dengan diketahuinya nilai rentang data maka dapat diperoleh panjang kelas interval untuk masing-masing kelompok yaitu 26/8 $=3,25$ dengan pembulatan menjadi 4. Tabel distribusi frekuensi ditampilkan sebagai berikut.

Tabel 3. Distrbusi Frekuensi Variabel Persepsi Mahasiswa tentang Program PPG

\begin{tabular}{|c|c|c|c|}
\hline No. & Interval & Frekuensi & Persentase \\
\hline 1. & $34-37$ & 17 & 11,19 \\
\hline 2. & $38-41$ & 15 & 9,87 \\
\hline 3. & $42-45$ & 30 & 19,73 \\
\hline 4. & $46-49$ & 43 & 28,29 \\
\hline 5. & $50-53$ & 23 & 15,13 \\
\hline 6. & $54-57$ & 18 & 11,85 \\
\hline 7. & $58-61$ & 6 & 3,94 \\
\hline 8. & $62-65$ & 0 & 0 \\
\hline \multicolumn{2}{|c|}{ Total } & 152 & 100 \\
\hline
\end{tabular}

Hasil distribusi tabel frekuensi yang ditampilkan dalam tabel 3 digambarkan dalam gambar 3 sebagai berikut:

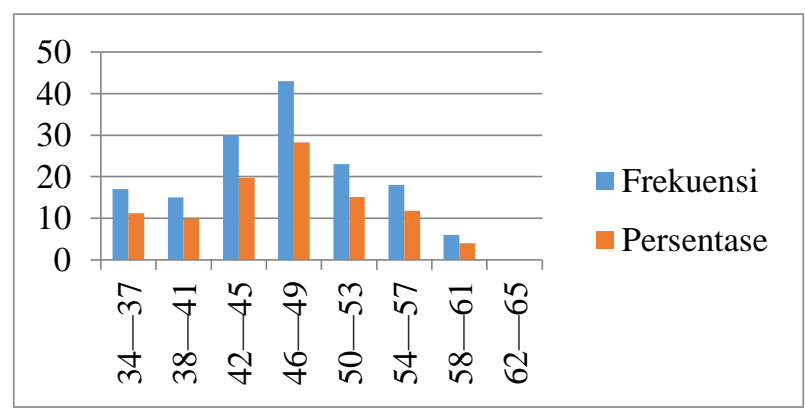

Gambar 3. Diagram Frekuensi

Selanjutnya dilakukan pengkategorian variabel, untuk mengetahui berapa besar kecenderungan tiap variabel maka dilakukan pengkategorian menjadi 5 kategori sebagai berikut:
Tabel 4. Pengkategorian variabel persepsi tentang program PPG

\begin{tabular}{|c|c|c|c|}
\hline No. & Kategori & Frekuensi & Persentase \\
\hline 1. & Sangat tinggi $(X>53,495)$ & 24 & 15,79 \\
\hline 2. & Tinggi $(49,165<\mathrm{X} \leq 53,495)$ & 23 & 15,13 \\
\hline 3. & Sedang $(44,835<\mathrm{X} \leq 49,165)$ & 52 & 34,21 \\
\hline 4. & Rendah $(40,505<\mathrm{X} \leq 44,835)$ & 25 & 16,45 \\
\hline 5. & Sangat rendah $(\mathrm{X} \leq 40,505)$ & 28 & 18,42 \\
\hline \multicolumn{2}{|r|}{ Total } & 152 & 100 \\
\hline
\end{tabular}

Berdasarkan tabel 4, diketahui bahwa persepsi mahasiswa tentang program PPG dalam kategori sangat tinggi berjumlah 24 sampel (15,79\%), tinggi berjumlah 23 sampel $(15,13 \%)$, sedang berjumlah 52 sampel $(34,21 \%)$, rendah berjumlah 25 sampel $(16,45 \%)$, dan sangat rendah yang berjumlah 28 sampel $(18,42 \%)$.

Untuk variabel persepsi mahasiswa tentang program PPG memiliki nilai rata-rata sebesar 46,49 yang berada pada kelas interval sedang. Sehingga dapat disimpulkan bahwa persepsi mahasiswa tentang program PPG termasuk dalam kategori yang sedang.

Berdasarkan tabel 4, pengkategorian variabel dapat digambarkan pada gambar 4 sebagai berikut:

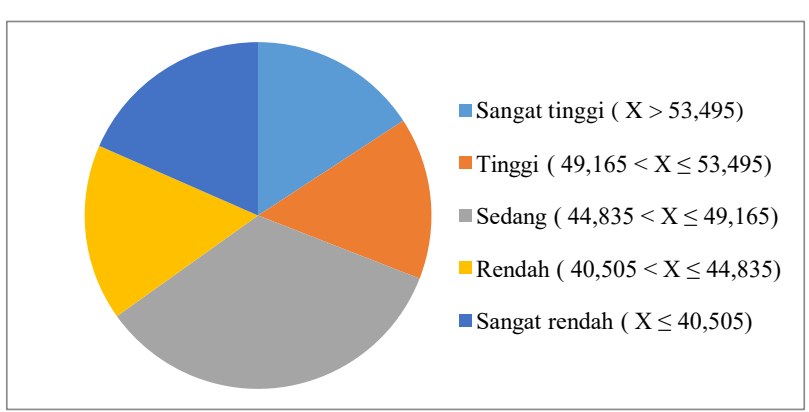

Gambar 4. Lingkaran Pengkategorian Variabel Persepsi tentang Program PPG

3. Persepsi Mahasiswa Tentang Profesi Guru $\left(\mathrm{X}^{2}\right)$

Variabel persepsi mahasiswa tentang profesi guru memiliki 31 butir pernyataan valid dengan responden sebanyak 152 mahasiswa. Untuk 
variabel ini diperoleh hasil analisi sebagai berikut: nilai maksimum 170; nilai minimum 134; Modus (Mo) 155; Median (ME) 152; Mean (M) 151,99; dan Standar Deviasi (SD) 9,959.

Jumlah kelas interval diperoleh sejumlah 8 kelas yang diperoleh dengan menggunakan rumus $1+3,3 \log \mathrm{n} .(1+3,3 \log 152)=8,2$ Untuk rentang data dalam variabel ini yaitu sebesar $170-134=36$, dengan diketahuinya nilai rentang data maka dapat diperoleh panjang kelas interval untuk masingmasing kelompok yaitu $36 / 8=4.5$ sehingga dibulatkan menjadi 5. Berikut ini merupakan hasil untuk tabel distribusi frekuensinya yang tersaji dalam tabel 5 .

Tabel 5. Distribusi Frekuensi Variabel Persepsi Tentang Profesi Guru

\begin{tabular}{|c|c|c|c|}
\hline No. & Interval & Frekuensi & Persentase \\
\hline 1. & $134-138$ & 16 & 10,52 \\
\hline 2. & $139-143$ & 21 & 13,81 \\
\hline 3. & $144-148$ & 19 & 12,5 \\
\hline 4. & $149-153$ & 30 & 19,74 \\
\hline 5. & $154-157$ & 23 & 15,14 \\
\hline 6. & $158-162$ & 11 & 7,23 \\
\hline 7. & $163-167$ & 22 & 14,48 \\
\hline 8. & $168-172$ & 10 & 6,58 \\
\hline \multicolumn{2}{|c|}{ Total } & 152 & 100 \\
\hline
\end{tabular}

Hasil distribusi tabel frekuensi yang ditampilkan dalam tabel 5 digambarkan dalam gambar 5 sebagai berikut:

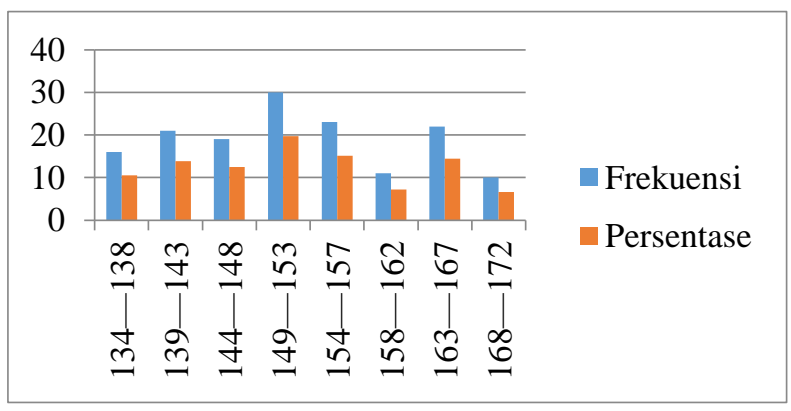

Gambar 5. Diagram Batang Distirbusi Frekuensi Persepsi tentang Profesi Guru
Selanjutnya dilakukan pengkategorian variabel, untuk mengetahui berapa besar kecenderungan tiap variabel maka dilakukan pengkategorian menjadi 5 kategori sebagai berikut:

Tabel 6. Pengkategorian Variabel Persepsi tentang Profesi Guru

\begin{tabular}{|c|c|c|c|}
\hline $\begin{array}{c}\text { No } \\
.\end{array}$ & Kategori & Frekuensi & Persentase \\
\hline 1. & Sangat tinggi $(\mathrm{X}>161)$ & 32 & 21,05 \\
\hline 2. & Tinggi $(155<\mathrm{X} \leq 161)$ & 22 & 14,48 \\
\hline 3. & Sedang $(149<\mathrm{X} \leq 155)$ & 34 & 22,36 \\
\hline 4. & Rendah $(143<\mathrm{X} \leq 149)$ & 27 & 17,77 \\
\hline 5. & Sangat rendah $(\mathrm{X} \leq 143)$ & 37 & 24,34 \\
\hline \multicolumn{2}{|c|}{ Total } & 152 & 100 \\
\hline
\end{tabular}

Berdasarkan tabel 6 di atas, diketahui bahwa persepsi mahasiswa tentang profesi guru dalam kategori sangat tinggi berjumlah 32 sampel (21,05\%), tinggi berjumlah 22 sampel (14,48\%), sedang berjumlah 34 sampel $(22,36 \%)$, rendah berjumlah 27 sampel $(17,77 \%)$, dan sangat rendah yang berjumlah 37 sampel $(24,34)$. Untuk variabel persepsi mahasiswa tentang profesi guru memiliki nilai rata-rata sebesar 151,99 yang berada pada kelas interval sedang. Sehingga dapat disimpulkan bahwa persepsi mahasiswa tentang program PPG termasuk dalam kategori yang sedang.

Berdasarkan tabel 6, pengkategorian variabel dapat digambarkan pada gambar 6 sebagai berikut:

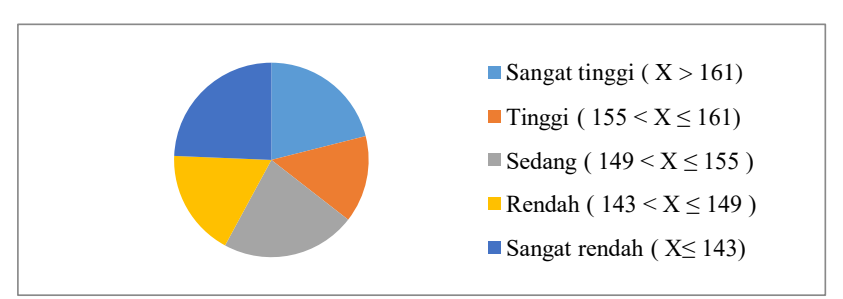

Gambar 6. Diagram Lingkaran Pengkategorian Variabel Persepsi tentang Profesi Guru 


\section{Minat Menjadi Guru Dipengaruh oleh Persepsi Mahasiswa tentang Program PPG}

Dari hasil penelitian ini terungkap bahwa dari 152 responden penelitian variabel X1 berada pada kategori sedang sebanyak 52 orang atau dengan persentase sebesar $34,21 \%$, dengan kata lain hasil perhitungan ini menunjukkan bahwa persepsi mahasiswa Program Studi Pendidikan Guru Madrasah Ibtidaiyah UIN Raden Fatah Palembang memiliki tentang program PPG berada pada kategori sedang.

Persepsi seseorang akan berpengaruh pada prilaku yang bersangkutan. dengan demikian tingkat persepsi mahasiswa tentang program PPG dengan kualitas yang memadai berpengaruh positif terhadap minat mahasiswa untuk menjadi seorang guru.

Temuan dalam penelitian ini menunjukkan kecenderungan persepsi mahasiswa tentang program PPG mempengaruhi minat mereka untuk menekuni profesi guru. Pengetahuan mahasiswa tentang program PPG, akan berbanding lurus dengan minat mahasiswa menjadi guru. Karenanya diperlukan upaya sosialisasi program PPG melalui paparan oleh dosen dan media lainnya kepada mahasiswa.

Beberapa responden $(16,81 \%)$ berasumsi bahwa profesi guru hanya dibatasi pada aktifitas mengajar dan mendidik saja, pada kelompok ini belum menyadari bahwa kegiatan lain berupa penyususnan rencana pembelajaran (RPP), program Semester, Program Tahunan dan Program Kurikulum merupakan bagian penting yang menjadi tanggung jawab utama dalam profesi guru. responden lain dengan jumlah yang lebih kecil justru berasumsi bahwa tersedia peluang pekerjaan selain profesi guru bagi mereka yang menempuh pendidikan di PGMI misalnya pada sector perbankan dan sector formal lainnya sehingga minat untuk menjadi guru maki menipis dibeberapa responden yang dimaksud.

Minat menjadi guru merupakan modal penting bagi seseorang dalam pilihannya untuk menekuni profesi guru sebagai sandaran masa depan kehidupan dan karirnya, dengan demikian diperlukan peningkatan informasi agar tidak muncul keraguan dikalangan mahasiswa dalam memupuk niatnya agar kelak menjadi guru yang profesional.

\section{Minat Menjadi Guru Dipengaruhi oleh Persepsi Mahasiswa tentang Profesi Guru}

Dari hasil penelitian ini peneliti menemukan bahwa dari 152 responden penelitian, persepsi mahasiswa tentang profesi guru masuk pada kategori sedang dimana jumlah responden sebanyak 34 orang atau pada tingkat 22,36\%, ini berarti bahwa mahasiswa Program Studi Pendidikan Guru Madrasah Ibtidaiyah UIN Raden Fatah Palembang memiliki persepsi tentang profesi guru pada kategori sedang dan Secara umum mayoritas mahasiswa Pendidikan Guru Madrasah Ibtidaiyah UIN Raden Fatah Palembang, memiliki persepsi tentang profesi guru yang baik.

Dalam penelitian ditemukan tentang persepsi responden tentang profesi guru mempengaruhi minat untuk menjadi guru secara signifikan dengan nilai signifikansinya $<0,05$. Ini berarti bahwa mayoritas responden yang mempunyai persepsi tentang profesi guru yang baik akan memliki minat untuk menjadi seorang guru yang tinggi. Dengan kata lain pemahaman profesi guru merupakan salah satu faktor yang dapat mempengaruhi minat mahasiswa menjadi guru.

Minat seseorang tidak lahir begitu saja namun terdapat beberapa faktor yang mempengaruhinya, yang salah satunya adalah persepsi (Dalyono, 2009). Persepsi memberikan 
pengaruh pada minat melalui perspektif mahasiswa tentang obyek, kejadian, yang disaksikan, didengar, dan dirasakan (Alim, 2016). Pernyataan tersebut memberikan arti bahwa persepsi tentang profesi guru dapat memberikan pengaruh bagi mahasiswa untuk menumbuhkan minatnya menjadi guru. Persepsi mahasiswa terhadap profesi guru yang memadai mutlak diperlukan untuk menumbuhkan semangat mahasiswa agar termotivasi meningkatkan pengetahuan dan kompetensi pendukungnya bagi tujuan menjadi guru yang berkualitas dan profesional. Persepsi mahasiswa terhadap profesi guru juga memberikan arah perubahan pandangan para mahasiswa bidang kependidikan yang mulanya hanya memandang profesi guru sebagai suatu pekerjaan biasa khususnya terkait kesejahteraan (faktor ekonomi) dengan pandangan miring yang mempersepsikan profesi guru sebagai suatu pekerjaan yang tidak memberikan jaminan masa depan bagi kesejahteraan para pelakunya. Dengan pemahaman yang tepat atas profesi guru maka persepsi-persepsi positif akan mampu menumbuhkan minat mahasiswa untuk menjadi guru, yang bukan semata-mata karena faktor kesejahteraan namun lebih kepada kepuasan kerja karena kebanggaan atas profesionalitas pekerjaan guru.

\section{Minat Menjadi Guru Dipengaruhi secara Bersamaan oleh Persepsi Mahasiswa tentang Program PPG dan Profesi Guru terhadap Minat Menjadi Guru}

Hasil analisis pada uji simultan didapatkan hasil untuk nilai $\mathrm{F}$ hitung sebesar 91,276 dengan nilai signifikansi sebesar 0,000. Memperlihatkan bahwa persepsi mahasiswa tentang program PPG dan profesi guru secara bersama-sama mempunyai pengaruh yang signifikan terhadap minat menjadi guru pada mahasiswa Pendidikan Guru Madrasah Ibtidaiyah Universitas Islam Negeri Raden Fatah Palembang.

Pada hasil analisis regresi berganda memperlihatkan bahwasanya nilai koefisien determinasi $\left(\mathrm{R}^{2}\right)$ sebesar 0,551 atau $55,1 \%$. yang berarti bahwa untuk variabel persepsi mahasiswa tentang program PPG dan profesi guru mempunyai pengaruh terhadap minat mahasiswa untuk menjadi guru sebesar $55,1 \%$ sisanya sebesar $44,9 \%$ dipengaruhi oleh variabel lain yang tidak diteliti dalam penelitian ini.

\section{Kesimpulan}

Berdasarkan hasil penelitian dan pembahasan di atas, maka dapat disimpulkan bahwa pertama, persepsi mahasiswa tentang program PPG memberikan pengaruh positif secara signifikan terhadap minat menjadi guru. Pembuktian dilakukan melaui hasil nilai koefisien garis positif untuk variabel persepsi mahasiswa tentang program PPG sebesar 0,723 dengan nilai $t$ sebesar 9,139 dan signifikansi 0,000. Kedua, minat menjadi guru juga dipengaruhi oleh persepsi mahasiswa tentang profesi guru secara positif dan signifikan. Pembuktiannya ditunjukkan melalui hasil nilai koefisien garis positif untuk variabel persepsi mahasiswa tentang profesi guru sebesar 0,201 dengan nilai t sebesar 3,994 dan signifikansi 0,000. Dan ketiga, kedua variabel secara bersamasama berpengaruh positif dan signifikan terhadap minat menjadi guru mahasiswa Pendidikan Guru Madrasah Ibtidaiyah Universitas Islam Negeri Raden Fatah Palembang. 


\section{Daftar Pustaka}

Alim, A. F. (2016). Faktor-Faktor yang Mempengaruhi Minat Profesi Guru Mahasiswa Program Studi Pendidikan Teknik Bangunan (S1) Jurusan Teknik Sipil FT UNP. CIVED (Journal of Civil Engineering and Vocational Education), 4(1).

Arifin, Z. (2011). Evaluasi Pembelajaran Prinsip, Teknik, Prosedur. Remaja Rosdakarya.

Baharuddin, \& Makin, M. (2010). Manajemen Pendidikan Islam Transformasi Menuju Sekolah/Madrasah Unggul. UIN Maliki Press.

Dalyono, M. (2009). Psikologi Pendidikan. Rineka Cipta.

Djam'an, S. (2007). Profesi Keguruan. Universitas Terbuka.

Hamalik, O. (2010). Proses Belajar Mengajar. Bumi Aksara.

Hidayatullah, F. (2009). Guru Sejati Membangun Insan Berkarakter Kuat Dan Cerdas. Yuma Pustaka.

Khairani, M. (2017). Psikologi belajar. Aswaja Pressindo.

Slameto. (2015). Belajar dan Faktor-Faktor yang Mempengaruhi. Rineka Cipta.

Syah, M. (2013). Psikologi Belajar. Rajawali Pers.

Yahya, M. (2013). Profesi Tenaga Kependidikan. Pustaka Setia. 